\title{
Casting for a Sovereign Role: Socialising an Aspirant State in the Scottish Independence Referendum
}

\section{Ryan K Beasley \\ University of St Andrews, UK \\ Juliet Kaarbo \\ University of Edinburgh, UK}

Accepted for publication in European Journal of International Relations, 13 November 2016.

\begin{abstract}
This paper examines international reactions to Scotland's 2014 bid for independence as an instance of socialisation of an aspirant state, what we term pre-socialisation. Building on and contributing to research on state socialization and role theory, this study proposes a nexus between roles and sovereignty. This nexus has three components - sovereignty itself is a role casted for by an actor, the sovereign role is entangled with substantive foreign policy roles the actor might play, and the sovereign role implicates the substantive foreign policy roles of other actors. The Scottish debate on independence provides an effective laboratory to develop and explore these theoretical dimensions of presocialization, revealing the contested value and meaning of sovereignty, the possible roles an independent Scotland could play, and the projected implications for the role of the UK and other international actors. Our analysis of the Scottish case can provide insights for other cases of pre-socialisation and is more empirically significant following the UK's 2016 referendum to leave the EU.
\end{abstract}

\section{Keywords}

socialisation, role theory, sovereignty, Scottish independence, United Kingdom

\section{Introduction}

In October 2012, Scottish First Minister Alex Salmond and UK Prime Minister David Cameron signed the Edinburgh Agreement, allowing Scotland to hold an independence referendum. The ensuing debate centred around the 'Yes' 
side, mainly the Scottish National Party (in power in the Scottish executive since 2007) versus the 'No' side (later changed to 'No, thanks,'), mainly the Better Together campaign (an umbrella organisation). Although this matter was for eligible voters of Scotland to decide, external actors also weighed in, contesting Scotland's potential roles as a sovereign state. We argue that the case demonstrates a crucial interplay between sovereignty and roles. This is the first theoretically-focused empirical analysis of the international dimension of the Scottish referendum.

We focus on the period when the international community became interested in the question of an independent Scotland (from 2012 to the 18 September 2014 vote). ${ }^{1}$ Previous moves increasing Scottish autonomy (including the 1997 referendum that endorsed devolution) did not attract much international attention, but the political transition from seeking devolution to seeking independence highlighted for international actors the importance of this case (Walker, 2014). A new Scottish state would have significant implications for international institutions such as the EU and NATO, the remainder of the UK, and other independence movements. Although the 'Yes' side failed to achieve its independence bid, the case is more salient following the 2016 British referendum to leave the European Union (Brexit) vote, in which English and Welsh majorities favored a departure while a substantial majority in Scotland voted to remain (BBC News 2016a), reigniting independence discussions.

We use the Scottish case to develop a conception of socialisation prior to statehood - what we term pre-socialisation - which involves a fundamental interplay between international conceptions of sovereignty and foreign policy roles. This sovereignty-role nexus manifests itself in the pre-statehood period through role forecasting, where actors contest the nature and value of sovereignty through the role transformations that could hypothetically be produced in the event of statehood. This symbolic-interactionist account of international state formation advances our understanding of both role theory and state socialisation by viewing roles as constructed repositories of

1 The long history of Scottish-English relations, from $10^{\text {th }}$ century border wars to the election of the first modern Scottish parliament with devolved powers in 1999 undoubtedly affected the referendum debate, but is beyond our focus here. 
sovereignty within international society. The Scottish case in particular isolates this by bracketing other factors often associated with the establishment of statehood; there was no rejection of international norms, no military conflict, and the bid for independence was accepted by the home state. This analysis not only helps us understand the Scottish independence referendum, but also has broader applicability to other independence movements, as well as role transformations related to sovereignty.

\section{Theoretical foundations of state socialisation}

State socialisation is an important process in international relations, affecting 'the formation and change of preferences; national identity formation; the creation, diffusion of, and compliance with international norms; and the effects of international institutions' (Johnston 2001:489). Socialisation is referenced in a wide-ranging set of IR theories. Neorealism, for example, includes socialisation as processes of selection and competition in which anarchy moulds states into like units (e.g. Waltz 1979; for discussion see Alderson 2001; Checkel 2005; Thies 2010b). Socialisation as norm internalization or adaptation is also an important part of liberal-oriented perspectives, including regime theory, international legal approaches, and rationalist institutionalism (Alderson 2001; Schimmelfennig 2000). English School perspectives include socialisation as the process by which the international society generates common interests, values, and rules (Cantir 2011; Checkel 2005; Schimmelfennig 2000). For constructivists like Wendt, socialisation is 'a ubiquitous feature of interaction in terms of which all identities and interests get produced and reproduced' (Wendt 1992: 403 fn 42; see also Schimmelfennig 2000).

Despite the importance of socialisation in IR theories, there are two significant limitations to this research. First, most of these studies use normbased definitions of socialisation (exceptions include Cantir 2011; Schimmelfennig 2000). Second, socialisation theories have almost exclusively assumed the existence of states as their starting point. Once states come into existence, theorists differ with regard to how they are socialised into the international order, but socialisation efforts prior to statehood-pre-socialisation - are not specified. This leaves important factors unexamined, such as the 
relationship of sovereignty to socialisation and the process of constructing agency prior to membership in international society. Departing from normative approaches by using Thies's argument that socialisation can be conceptualised as a process of role location, we extend this approach by developing expectations about the key features of pre-socialisation.

\section{Socialisation: norms and roles}

In the influential special issue on socialisation in International Organization, Checkel (2005: 804) defines socialisation as 'a process of inducting actors into the norms and rules of a given community. Its outcome is sustained compliance based on the internalization of these new norms.' This definition reflects what Johnston calls a general agreement across the social sciences that socialisation is 'social interaction that leads novices to endorse "expected ways of thinking, feeling, and acting"' (Johnston 2001: 494; citing Stryker and Stratham 1985:325). English-school inspired research also conceptualises socialisation as a process resulting in conformity to societal conventions (Armstrong 1993:7-8). Constructivist research embraces socialisation as norm internalisation, examining different mechanisms and effectiveness of socialisation efforts, particularly in highly institutional contexts (e.g., Checkel 2005; Flockhart 2004).

Conceptualising socialisation as norm internalisation is problematic as it presents too limited a vision, first with regard to the potential for socialisation to fail and second with regard to neglect of non-normative aspects. According to Thies (2003: 544), 'the focus on internalisation is common in current international relations thinking about socialisation, but...defining socialisation by the degree of internalisation has generally been discarded in sociology.' This is because actors may simply adapt their behaviour to comply with others' expectations, but not internalise norms. Actors may also completely reject socialisation efforts, even if there are high subsequent costs. Defining socialisation more broadly, as 'activity that confronts and lends structure to the 
entry of non-members into an already existing world' (Wentworth 1985:5) ${ }^{2}$ or society -- is more inclusive, and allows socialisation to fall short of internalisation.

Thies also argues that socialisation could involve norms, "but might also include roles, beliefs, principles, or rules' (2003: 545). ${ }^{3}$ Thies advances roles as a fruitful concept to capture socialisation since roles are 'repertoires of behaviour, inferred from others' expectations and one's own conceptions, selected at least partly in response to cues and demands' (Walker 1992: 23) and represent social positions within groups of actors (Thies 2003). States, for example, may play a variety of roles, such as 'faithful ally,' 'great power', or 'bridge' (Holsti 1970). Socialisation, then, can involve processes by which existing members shape roles available to new members. Thies argues that 'the use of roles allows us to draw on a variety of established social psychological theories...and a variety of role theories, all of which have well-developed views on socialisation' (2003:545) and that 'role theory's articulated views on the socialization process stand in stark contrast to the underdeveloped models of socialization associated with norms' (2010b: 696). ${ }^{4}$ This broader perspective also provides opportunities to examine cases of socialisation where norms are largely uncontested (as in the Scottish case), yet states are nevertheless being socialised.

\section{Socialisation: a role theoretic perspective}

A role theoretic analysis of pre-socialisation allows us to draw on and contribute to role theory research, which has blossomed in recent years. ${ }^{5}$ Role theory is exceptionally rich conceptually, theoretically and ontologically, integrating several concepts (e.g. beliefs, identities, material and normative structures, interaction, agency, behaviour) important for understanding foreign

\footnotetext{
${ }^{2}$ As quoted in Thies $2010 \mathrm{~b}$.

${ }^{3}$ Italics in original.

${ }^{4}$ For convenience and in terms of customary use, we adopt the terms "role theory" even though we agree that it is not a theory per se, but more a theoretical framework.

${ }^{5}$ Recent efforts include Harnisch, Frank, and Maull (2011), a special issue of Foreign Policy Analysis edited by Thies and Breuning (2012), and Harnisch, Bersick, and Gottwald (2016).
} 
policy and international relations. ${ }^{6}$ It provides a conceptual tool-kit for understanding complex social processes, and operates at multiple levels of analysis, bridging agents and structures; several scholars have noted this as one of its distinct advantages (e.g., Barnett 1993; Thies 2010b; Harnisch 2011; Breuning 2011).

Rooted in symbolic interactionism, role theory includes socialisation processes and differs from a structural-functionalist perspective in which 'roles are sets of rights and duties attached to particular social positions' and emerge from interactions' (McCourt 2012: 376). Roles are created through a process of Ego (the role-seeking state) interacting with Alters (others) and are not fixed or pre-determined, but conditional on Alters' acceptance (Aggestam 2006; Harnisch 2011; McCourt 2012; Wehner and Thies 2014; Beneš and Harnisch 2015). According to Wehner (2014:4), 'a symbolic-interactionist approach brings...to the fore the social nature of the structure, the nonreification of it, and the importance of the actors' agency capacity to cast and change roles based on the interaction' of Ego and Alters.

From a role theory perspective this interaction, or role location process, is socialisation. That is, states locate roles through interactive socialisation 'where role expectations of the self and other, role demands of the situation, and cues from the audience all come together to produce a role for the actor and set the conditions for its appropriate enactment' (Thies 2013:35). Socialisation 'focuses on the role taking of an actor in an existing social structure' (Harnisch 2016). ${ }^{7}$ Thies's (2012) compelling study on the 'novice' state, for example, analyses Israel and the United States in early statehood. He shows the interactions through which 'novices' are socialised and demonstrates the challenges for

\footnotetext{
${ }^{6} \mathrm{~A}$ full review of role theory research in international relations is beyond our scope. Seminal works include Holsti 1970; Wish 1980; Walker 1987. For recent overviews, see, Thies 2010a; Harnisch 2011; Breuning 2011; and Wehner and Thies 2014.

${ }^{7}$ Role theory's concept of 'alter-casting' is related to socialisation as both involve others' reactions and role expectations. Harnisch (2016), however, argues altercasting is different in that it involves Alters changing their own role to structure the possible roles of Ego (see also Thies 2016). In pre-socialisation, these roles are hypothetical, yet to be enacted. We suggest that the more general concept of socialisation in which Alters signal their preferences for Ego's future roles better captures the dynamics of pre-socialisation.
} 
newcomers to the international society. While his examination is thorough, he offers no justification for beginning his analysis after statehood. The focus on the 'novice' state begs the question: how are actors socialised prior to statehood?

Role theory research, like most socialisation work within International Relations, assumes sovereign states as a starting point (Coggins 2011). Wendt (1992), for example, allows anarchy and the international system to be constructed by states, but does not specify how Ego and Alter themselves are socially constructed as states. Presumably, however, agents are constructed prior to statehood, as societies do not only admit and then socialise members, but also form members from existing actors. With its symbolic-interactionist perspective role theory is especially suited to examine the pre-state processes of socialisation as states make and re-make one another in a continuous process of interpretation and construction of meaning and identity. In the modern international system new states have typically formed by reformulating existing states (Fabry 2010; Coggins 2011). Thus socialisation can conceivably apply before a new state is formally recognised as such. From this point of view, if anarchy is what states make of it, pre-socialisation is what makes sovereign states.

\section{Pre-Socialisation: The Sovereignty-Role Nexus}

The key factor distinguishing socialisation before and after statehood is sovereignty. We propose a 'sovereignty-role nexus' is central to the presocialisation process, which is comprised of three aspects. First, as Barnett (1993) and Thies (2013) have demonstrated, sovereignty itself can be treated as a type of role. Second, we argue that in pre-socialisation this sovereign role becomes interconnected with substantive foreign policy roles an actor might play if it becomes sovereign. Third, given the social system of states, we propose that the potential sovereign role becomes entangled with the substantive foreign policy roles that other actors play. All three aspects of the sovereignty-role nexus affect pre-socialisation. After developing these theoretical propositions, we use the Scottish case to illustrate the connections between sovereignty and roles during the independence referendum. 
Role theory brings our attention to the relational and interactive dimensions of sovereignty. From a symbolic interaction perspective, sovereignty is not an ability or capacity that is necessary to enable agency and enact roles, but is a consequence of defining agency itself. That is, sovereignty is not a structural-functionalist 'status' that is conferred on an aspirant state based on its ascribed characteristics, but instead arises from the social interaction process wherein the possibility and appropriateness of sovereignty can be debated and contested. We suggest that during pre-statehood these processes actually construct the 'sovereign role' and this role becomes part of the repertoire of presocialisation, effectively giving Alters a foundational way to support or oppose role enactment sought by an aspirant state. International debate over independence is not confined to the type of foreign policy role (discussed below) the state might or might not play, but also includes the desirability and feasibility of an actor taking on the role of sovereign state. Pre-socialisation takes the form of instructing a potential state about the nature, value, and meaning of the sovereignty it seeks. In this way, sovereignty itself is a role within the society of states, which Ego can seek to enact and Alter(s) can seek to accept, reject, and shape just as with other roles. This is the first aspect of the sovereignty-role nexus.

The sovereign role will be significantly affected by the meaning of sovereignty within the international system. As Philpott (1995) argues, 'we can read the essential character of any era in international relations through its norms of sovereignty' (p.360) which function at the international level and provide answers to three questions: what are the legitimate polities (e.g. states), who can become one, and what powers does sovereignty confer? Philpott claims there have been several revolutions in sovereignty since the Treaty of Westphalia that have transformed the norms of sovereignty, resulting in different legitimate polities, actors, and powers. Pre-socialisation reflects these conceptions of sovereignty and the value and applicability of a sovereign role for the aspirant state.

We propose that these different conceptions of sovereignty shape the roles available within the international system. Indeed, all roles imply something about sovereignty, and some roles, including some in Holsti's (1970) 
original inventory of roles, are defined largely along sovereignty lines (e.g. 'independent', 'colony'), rather than primarily on capabilities (e.g. 'great power') or character (e.g. 'mediator,' 'faithful ally'). In this way, the sovereignty-role nexus links prevailing conceptions of sovereignty, and the sovereign role, to the substantive types of roles available within the international society. This is the second key aspect of the sovereignty-role nexus.

The early Cold War period, for example, saw 'great power' roles, 'faithful allies', and 'dependents'. According to Philpott, however, the subsequent era of colonial independence saw a change in conceptions of sovereignty. States were retained as the polities with similar powers, but new norms allowed former colonies to become sovereign. This period of decolonisation, where norms of sovereignty were extended to former colonies as legitimate actors, arguably helped create a new set of roles premised on maintaining and extending that sovereignty ('independent'; 'non-aligned'; see Wish 1980; Walker 1987). European integration, Philpott (2001) argues, has more recently challenged the widespread acceptance of the sovereign state system. The EU transformed all three aspects of sovereignty, allowing its institutions to pool states' sovereignty, setting up criteria for membership, and altering the legitimate powers of individual states. Within the European theatre, this transformation in sovereignty around the integration of the EU made new roles possible, such as 'civilian power' (Duchêne 1972; Maull 1990) and 'normative power Europe' (Manners 2002).

Thus, an extant society of states constructs the role of a sovereign state toward which potential states must aspire, and different substantive roles become possible for new states to seek depending on how sovereignty itself is constructed. Of course roles are also defined by material resources, culture, norms, and leaders' beliefs (e.g., Wish 1980; Aggestam 2004; Breuning 2011), but we argue that prevailing notions of sovereignty are central to roles. In presocialisation, the connection between sovereignty and substantive roles is most evident: whether or not an actor should become sovereign is bound up in what type of role it would play, and what roles it can play are shaped by the prevailing conceptions of sovereignty. 
Thus pre-socialisation efforts must by necessity work along a sovereignty-role nexus where the taking of a sovereign role and the taking of a substantive role are simultaneously engaged. The substantive role that a new actor would take is not fully known--it is hypothetical: if the actor becomes sovereign, then it might or might not play certain roles. Thus, forecasting in presocialisation not only involves questions about whether an aspirant state should be sovereign, but also what kind of roles it should take.

The third way in which sovereignty and roles are connected in presocialisation follows from role theory's conception of roles interacting in a social system. As roles are relational, a new state gaining sovereignty and enacting new roles may transform the roles of the home state from which independence would be achieved, and this may have significant consequences for others. While all roles are interdependent, role entanglement in a bid for sovereignty is of a special nature, as it arises between the aspiring state and the home state because of the sovereignty question. Thus the co-constitutive nature of roles prompts, in the pre-socialisation period, questions about how the home state would change and what benefits would be possible or foregone if it can no longer play its substantive foreign policy roles. Others in the role system may have considerable interests in the home state's role(s) and may oppose or support independence based on the hypothetical forecasting of the home state's role. Thus, pre-socialisation efforts may involve as much about the home state as they do about the aspirant state.

An aspirant state's sovereign role may be concerning to other states for reasons beyond the direct effect on the home state. Sovereignty is clearly valued by all who have or seek it, but others may seek to ration and regulate sovereignty to maintain the status quo (Fabry 2010). States vulnerable to secession themselves may worry about precedents for secession and the consequences to their own sovereignty and indeed their own roles in the world (Saideman 1997; Coggins 2011). Others may oppose secession not out of concern for direct effects on themselves, but because independence challenges prevailing norms of sovereignty and conceptions of the sovereign role (Philpott 1995). This is related to the first aspect of the sovereignty-role nexus, but differs. In the first aspect, the value of sovereignty is questioned for the aspirant state. In this third 
aspect, others' reactions to independence are motivated by the consequences of independence for the prevailing norms of sovereignty. Others' positions on the sovereign role of an aspirant state may stem from broader concerns about effects on the sovereign system. From an English School perspective, gatekeepers oppose new states to maintain the current system of rules and norms (e.g., Bull 1977; Wight 1977; Armstrong 1993). Here, however, gatekeepers also worry about the consequences a new sovereign state might have for others' roles, role conflicts, and a fragmentation of the sovereign system.

In sum, pre-socialisation reveals three interrelated connections between sovereignty and roles - sovereignty as a role itself, sovereignty and substantive foreign policy roles, and the sovereign role's consequences for others' roles and the international community. Our approach has obvious links to research on the social construction of sovereignty (e.g., Barnett 1993; Biersteker and Weber 1996), on state formation, particularly social-constituitive perspectives on recognition (e.g., Fabry 2010; Coggins 2011) and on changes in international society and the sovereign state system (e.g., Wight 1977; Jackson 2000). Our role theory approach to socialisation, however, does not solely focus on when and why other states formally recognize independently declared territories, nor on notions of international legitimacy about the rightful membership of the family of nations.

A role theory approach to sovereignty adds a behavioural component that is missing in other perspectives on new states. A sovereign role is not only socially constructed but also comes with expectations of how states would play the sovereign role. While 'norms of sovereignty' may be foundational to a given international society, roles add to this the repertoire of behaviours that a sovereign actor could enact. As such, they reveal the pursuits to which sovereignty will be applied. A role perspective on sovereignty also includes the behavioural implications for others. When a new sovereign state is constructed, others' roles may have to change, which may be the primary motivation for others' reactions to the aspirant state. State recognition, international legitimacy, and norm internalisation all provide insights into the management and expansion of international society, but role theory focuses our attention more 
squarely on the forecasting of behaviours and the interactive construction and contestation of sovereignty.

\section{Pre-socialisation in the 2014 Scottish debate on independence}

The Scottish case is well situated to examine the sovereignty-role nexus in pre-socialisation. Although often unstated, the focused and open democratic nature of the independence referendum produced explicit claims relating to role taking. The Scottish case may be rare in terms of state formation, coming as it does within a firmly established state within the EU, with the reluctant blessing of the home state to hold a binding, democratic referendum, and during a period where prevailing international and regional norms strongly support democracy and oppose military force in violation of sovereignty. But this case is an opportunity to examine pre-socialisation where important norms associated with 'norm internalisation' conceptions of socialisation were not in dispute. On virtually all major international and foreign policy issues--such as trade, defence, and multilateral institutions--both sides of the debate embraced the prevailing normative international and regional consensus.

The Scottish case also strips away many traditional concerns around an independence movement, leaving stark the question of sovereignty itself. There were no fears of internal or international violence, no regional conflict implications of a new territorial unit set free among hostile neighbours, and little worry about major economic shocks to the international system. Given this, a role theoretic approach to socialisation may have some explanatory power regarding the outcome of this important case. Our primary use of this case, however, is to illustrate the sovereignty-role nexus developed in the previous theoretical section. Drawing on Walker's (2014) analyses of international positions on the referendum, states' opinions expressed in the media, and statements by the 'Yes' and 'No' sides in Scotland, we examine pro-independence actors' attempts to forecast both a sovereign role and specific, substantive foreign policy roles for an independent Scotland (see also Beasley et al. 2016) We also examine key Alters' forecasting, analyse possible motivations for their positions, and discuss pro-independence Scottish reactions to international interventions in the Scottish debate. 
The international interest in this case was high and many were puzzled by the move for Scottish independence, asking:

'Why was part of the Scottish populace so determined to make a break after nearly 300 years of peaceful coexistence with England and Wales...and after so much interdependence and intermingling? Why was there a desire to exchange the comfort of belonging to a large, influential state for a small state's more precarious and marginal existence?' (Walker 2014:749).

Despite norms of non-interference in internal, democratic affairs, key external actors made moves to shape the internal independence debate, although many of these actions came late, close to the vote (Walker 2014). This hesitancy to take sides likely stemmed from the widely held expectation that the referendum would fail. Most external actors expected Scottish voters to 'see sense' in a costbenefit analysis and reject independence (Walker 2014) and public opinion surveys through most of the debate supported this expectation. ${ }^{8}$ When, in the spring of 2014, opinion polls indicated growing support for independence, foreign governments became aware 'that the hypothetical was becoming less hypothetical and that they had better take notice' (Walker 2014: 744). This tipping point for external socialisers, where 'role-actualisation' became possible, likely mobilised them to invest resources in pre-socialisation efforts.

When external actors did voice their opinions, they were largely negative. As Walker (2014: 743-744) noted: 'The political reconfiguration of the UK, an erstwhile global power that still plays a significant role in shaping and upholding international institutions...and has an especially close relationship with the United States, would not be a minor event' (Walker 2014). For some external actors, reactions to the referendum were simply about the short-term effects Scottish independence would have on their interests. RyanAir, for example, commented that independence might be economically good for its airline (Bennett 2014), and in India, the front page of the Hindustan Times warned its readers: 'Great Scot! Independence vote may up Scotch prices' (Nelson 2014).

\footnotetext{
${ }^{8}$ See, for example, What Scotland Thinks, at http://whatscotlandthinks.org/questions/should-scotland-be-an-independentcountry\#line
} 
But most of the international debate over Scottish independence, we argue, revolved around the nexus between sovereignty and roles.

\section{Forecasting Scotland for a sovereign role}

The independence campaign was largely based on the value of sovereignty itself. With a sovereign role, Scots would be able to make their own choices, in both domestic and foreign policies. Although devolved Scotland already controlled many internal policies (e.g., police, health care), the 'Yes' side argued independence would offer additional scope for more social democratic, less market-oriented political, economic, and social policies. Domestic policy promises included a 'fairer', more 'socially just', and 'greener' country (Baxter n.d.; Mccarthy 2014). As Scottish First Minister Salmond explained, 'This referendum is about the future of Scotland, and the future of Scotland should be in the hands of the people. We believe we can govern ourselves better than anyone else can' (C-SPAN 2014, 1:25:03).

The 'Yes' side's vision of sovereignty was very affirmative and functional. According to Bober, 'the SNP in its discourse before and during the referendum campaign presented a consistently positive conceptualization of sovereignty and independence, as both concepts were associated with such signifiers as (among others): fairness, wealth, potential, vision, healthy, better, economic development, a stable economy or strong public services' (Bober 2014:27). ${ }^{9}$ Sovereignty was positive in that it would remove political obstacles to achieving these goals. In his visits to other countries and in editorials in The Washington Post, First Minister Salmond (e.g., 2012) attempted to explain to external audiences, and reassure them these reasons behind the SNP's bid for independence.

The 'No' side questioned the value of sovereignty in an interdependent world, particularly for small states, and emphasized risks, uncertainties, and threats associated with independence (Bober 2014). As noted by Bober (2014)

\footnotetext{
${ }^{9}$ The debate over Scottish independence also revealed different conceptions of internal dimensions of sovereignty between the pro-independence side in Scotland and the anti-independence side in England. The English understanding was 'absolute' sovereignty, resting in parliament, whereas the Scottish conception was 'popular', residing with the people (Bober 2014).
} 
former Prime Minister Gordon Brown, one key Scottish spokesperson for the 'No' side, argued 'only by pooling its resources with its British neighbours, can Scotland successfully cope with globalization. In an interdependent world [in Brown's view]...Scottish sovereignty would signify an irresponsible marching against the tide and propose a $19^{\text {th }}$ century answer to $21^{\text {st }}$ century challenges' (Bober 2014: 30; Brown 2014). The UK government also clearly worked hard to articulate the limited value of sovereignty.

'The UK government...instructed each affected department in Whitehall to carry out an assessment of the costs of every kind that would fall on Scotland should it leave the Union. The result was the published series of 'Scotland Analysis Papers' [including papers on EU and international issues, security, and defence]. In addition, various select committees of the UK parliament issued their own reports,...emphasizing the costs to Scotland and denying or downplaying benefits that might accrue from independence.' (Walker 2014: 748). ${ }^{10}$

The external community generally also projected a negative view of sovereignty for Scotland. In a statement released through the Better Together campaign, former U.S. President Bill Clinton 'said he worried a 'long, complex negotiating process' would weaken the Scottish economy and had concerns about Scotland trying to keep the pound as its currency' (Sanchez 2014). The head of Shell Oil also publicly highlighted the risks and uncertainties of independence (Carrell 2014).

The 'No' side and the UK government emphasised the dangers of sovereignty, thus questioning the value of a sovereign role given that Scotland would be a small state in a big world. There were efforts to highlight Scotland's more limited capacity to exploit its North Sea oil resources than would be the case as part of 'the broad shoulders of one of the top 10 economies in the world...', clearly suggesting Scotland requires the UK's comparative strength to effectively manage this economic resource (Castle and Reed 2014). The 'No' side forecasted an independent Scotland into a weak, small state role that, although sovereign, would have difficulty enacting roles consistent with its interests and

10 See, for example, House of Commons Foreign Affairs Committee (2013) Foreign Policy Considerations for the UK and Scotland in the Event of Scotland Becoming an Independent Country, Sixth Report of Session 2012-13, London. 
values. This view saw an independent Scotland finding itself highly and asymmetrically dependent on others for economics and security and vulnerable to instability in the global economy.

The question of an independent Scotland's currency was central to the campaigns and raised the relationship between economic interdependence and political independence. The Scottish government and the 'Yes' side took the position that Scotland would be able to keep the pound. Contradicting this, George Osborne, UK Chancellor of the Exchequer, indicated there would be no chance of sharing the pound, with the other major UK political parties articulating the same position (Sparrow 2014). Salmond attempted to counter Osborne's position and accused the UK government of 'bullying' (Hardman 2014). Emphasising the reciprocal nature of interdependence and relying on a logic of rationality, the SNP repeatedly expressed the expectation that sharing the pound with an independent Scotland was in the UK's interests, stating 'it's quite clear that not sharing a currency would cost the rest of the country as much as it would cost Scotland' (Brittain 2014).

The sovereign role and the value of sovereignty was particularly prominent for some states where secessionist movements were active, such as Canada and Spain, who were concerned about Scottish independence as precedent. Indeed, the Spanish government was one of the first to react, soon after the Edinburgh Agreement in 2011 (Walker 2014: 746). Referring to separatist referendums, Spanish Prime Minister Rajoy said 'everyone in Europe thinks that these processes are enormously negative because they worsen the economic recession and increase poverty for everyone' (quoted in Johnson and Waterfield 2014). Other states with secessionist tensions offered similar characterizations. Canada's Prime Minister Stephen Harper stated that it would not be in 'global interests or frankly the interests of the people in those countries' for Scotland to become independent, and cited the ongoing challenges of globalisation and increased competition as problems that an independent Scotland could not solve alone' (The Scotsman 2014).

Foreign support for Scottish independence primarily came from independence movement leaders in other sub-state territories, including Québec, Bavaria, and Catalonia (The Telegraph 2014). Few states publicly supported a 
Scottish sovereign role. One exception was North Korea. An editorial from the government-supported news agency stated: 'I think that independence would be a very positive thing for Scotland. I believe that every person has the right to be a member of an independent nation, to have sovereignty, to live in peace and to enjoy equality' (The Telegraph 2014).

The 'Yes' side countered the negative view of sovereignty, and the proposition that globalisation makes sovereignty almost irrelevant, especially for small states. Sturgeon argued that small states could 'punch above their weight' and have influence disproportionate to their size (Sturgeon 2013). The 'Yes' side pointed out that most states in the world are small and that some play an active and leading role in international organisations. By prioritising their goals and concentrating their limited diplomatic resources, small states can carve out niche roles, champion specific issues, and broker agreements, as they often enjoy more credibility and neutrality than larger states because of their small size. The SNP often invoked (wealthy) Nordic examples as evidence of economically successful and influential small states, highlighting again the utility of a sovereign role (The Scottish Government 2013).

Overall, the SNP's conception of a sovereign role was 'clearly based on the assumption that even in an interdependent world, sovereignty involves internal as well as external possibilities to achieve the desired aims' (Bober 2014: 27; see also Adamson and Lynch 2014). Jackson characterises the Scottish nationalist elite as having a very inclusive, modern understanding of sovereignty, quoting First Minister Salmond's declaration: 'I'm a post-nationalist' (Jackson 2014:54). Influenced by the concept of a 'post-sovereign state', 'the nationalists were able to present their case for an independent state not as an isolationist one, but instead as internationalist in essence. It was (and remains) a well-argued attempt at the harmonious placing of self-governing Scotland (internal sovereignty) in various international bodies, as cooperation is required because of globalization (external sovereignty)' (Bober 2014: 27). This view of sovereignty, as internationalist, begs the question: what substantive foreign policy roles would an independent Scotland play? 
The substantive foreign policy roles the 'Yes' side forecasted for Scotland were intimately connected with the sovereign role (the second aspect of the sovereignty-role nexus). This connection was in the form of a hypothetical - if Scotland were sovereign (a value in and of itself), then it would also play, for example, civilian power, EU, NATO, and international peacekeeper roles. The 'white paper' Scotland's Future (Scottish Government 2013) established the 'Yes' campaign's vision of its foreign policy roles, which included both continuity and change. Continuity would be provided by on-going membership in international organisations (e.g., NATO and the EU) and a continued pro-trade orientation in foreign economic policies. ${ }^{11}$ But there would also be the possibility of change, as an independent Scotland could pursue values and interests somewhat distinct from those of the UK.

The 'Yes' campaign emphasised the 'different international priorities' that an independent Scotland would pursue, seen 'most clearly in matters of war and peace and in our relationship with the EU' (Scottish Government 2013:209). The pledge to rid an independent Scotland of nuclear weapons - UK nuclear Trident submarines are the only UK nuclear force and are stationed in Scottish waters was also grounded in principle, arguing 'Trident is an affront to basic decency with its indiscriminate and inhumane destructive power' and 'totally morally wrong' (Scottish Government 2013: 232; C-SPAN 2014 1:07:43). The 'Yes' campaign described an independent Scotland as a 'champion for international justice and peace,' committed to the values of 'international development, human rights, climate change, and climate justice' (Scottish Government 2013: 210, 225). Scottish defence forces would be used, in addition to national defence, to support international peacekeeping and humanitarian missions undertaken under the auspices of the UN, NATO, and the EU and in support of international law. The vision was thus one of Scotland as a good global citizen with a 'do no harm' principle, especially to developing countries, firmly embedded in its international role (Scottish Government 2013: 231).

11 For convenience, this paper concentrates on the Scottish National Party's leadership as the 'Yes' side. Not all parts of the pro-independence movement supported, for example, continued NATO membership. 
First Minister Salmond (2012) authored opinion editorials in The Washington Post and used his visits to other countries to forecast an independent Scotland's role. In one speech, for example, Salmond reassured outside actors that Scotland would be international, a supporter of democratic and cosmopolitan values, and would follow liberal, open economic policies (Walker 2014:750). Far from rejecting the most important prevailing norms and practices, the independence side emphasized that Scotland would continue to embrace them.

Opponents, both internal and external, to Scottish interdependence highlighted uncertainty about the substantive foreign policy roles an independent Scotland could play. NATO, for example, indicated that Scotland would have to apply as a new state and that membership would require unanimous agreement of all twenty-eight alliance members (Carrell 2013). The UK Foreign and Commonwealth Office stated that an independent Scottish state would have to start afresh in terms of its formal alliances, and links with every other sovereign state' (cited in Walker 2014: 749).12 The UK government published its own legal advice, stating that Scotland would immediately be outside the EU and the UN (The Guardian, 2013). Sovereignty would not open the door to new substantive roles, but instead foreclose them.

The ability of an independent Scotland to play an EU role was a key point of contention. The UK government consistently argued that Scotland would face serious obstacles to EU entry. For example, David Lidington, UK Minister for Europe, stated that 'I've been sat around the EU table for the last three years for many discussions about EU enlargement. It is the complexity, the timeconsuming nature of those negotiations, that the people of Scotland ought to bear in mind. It isn't straightforward.' (Liddington 2014). EU actors and other member-states also quickly cast doubt on automaticity of membership, thereby questioning Scotland's ability to define for itself a post-independence EU role. In December 2012, the EU Commission President declared that any new state would have to apply for EU membership, contra the Scottish government's claim that it would be able to renegotiate its membership from inside the EU (BBC

12 From Scotland Analysis: EU and International Issues, Cm 8765 (London: Foreign and Commonwealth Office, 2014), 5. 
News 2012b). Spain also used EU membership to cast uncertainty on an independent Scotland's role. On the eve of the vote, the Spanish Foreign Minister reiterated Spain's opinion that EU membership would not be automatic and would require unanimous support from EU member states (Roberts 2014). 'An independent Scotland would be forced to wait at least five years to join the EU and would then have to sign up to the euro, the Spanish government...warned' (Johnson 2014).

Forecasting against a Scottish EU role was not uniform, however. Graham Avery, the European Commission's honorary director general advised Scottish voters to dismiss the 'perplexing' and 'absurd' tactics suggesting Scotland would face a challenging process in acquiring EU membership. In response to assertions from the Presidents of the European Council and the European Commission that EU treaties would not apply to newly independent parts of current member states, Avery described this as 'not the whole truth' (BBC News 2014a). Other EU states also weighed in, with Czech president Vaclav Klaus and senior French senator specializing in foreign policy Joelle Garriaud-Maylam challenging EU leaders' positions, and stating that such threats from the UK government 'are not credible' and that an independent Scotland 'would stay in the European Union' (Herald Scotland 2014). The 'Yes' side noted that EU, as well as NATO and UN, membership were to be expected since it was in others' interest to have an independent Scotland in these arenas of international cooperation (e.g., Scottish Government 2014).

\section{Role implications for others}

Pre-socialisation during the run-up to the referendum also centred on the effects Scottish independence would have on the UK's role is the world, and the consequences for Europe and for global politics. These efforts illustrate the third aspect of the sovereignty-role nexus - the interconnectedness of a new actor's sovereignty with others' roles and the international system of roles.

On the eve of the referendum vote, Spain's Foreign Minister GarcíaMargallo warned that the UK 'would be damaged, its political-economic prestige undermined in the world, and the EU needs the UK' (quoted in Roberts 2014). Italian Prime Minister Enrico Letta cautioned: 'The UK is one of the pillars of the 
single market, of big international trade agreements and is so important in Europe that the consequence will be maybe the start of the true decline of the European Union. The sequence, the consequences of tomorrow's referendum, could be very, very dangerous' (quoted in The Telegraph 2014). Germany was also against a divided UK. Germany's Foreign Minister Steinmeier observed, 'A German foreign minister is well advised not to interfere in British domestic politics. But I would openly admit that I would rather see Great Britain remain together' (quoted in The Telegraph 2014). Interestingly, discussion of Scotland's potential role as an independent contributing EU member was foregone entirely.

Outside the government, but a key German actor nonetheless, one Deutsche Bank Chief economist warned: 'A 'Yes' vote for Scottish independence...would go down in history as a political and economic mistake as large as Winston Churchill's decision in 1925 to return the pound to the Gold Standard or the failure of the Federal Reserve to provide sufficient liquidity to the US banking system, which we now know brought on the Great Depression in the US' (quoted in The Telegraph 2014). Former Swedish Prime Minister Bildt also suggested that a 'Yes' vote could destabilise the UK and undermine the Northern Ireland peace process (The Scotsman 2014). Ireland expressed similar concerns, which according to Walker (2014), involved its proximity to the UK and the possible negative implications for the stability of peace in Northern Ireland.

The U.S. opposition to a sovereign role for Scotland was also intimately connected to the consequences for the UK's role. In addition to a general concern about the precedent separation could set for other regions and states, the U.S. worried about the weakening of the UK as an ally and the uncertainty of the UK's contribution to nuclear deterrence. These concerns were voiced in U.S.based elite opinion pages (King 2012; The Washington Post 2012; The New York Times, 2013) and early on in the debate, Hillary Clinton also said she would 'hate' to see Britain 'lose' Scotland (Sanchez, 2014; see also Walker 2014: 746; Brooks and Carrell 2014). The U.S. government, like others, initially adopted the official position that the referendum was strictly an internal UK affair. Yet 'within the US government, there was concern that its most dependable and influential ally would be diminished by Scotland's departure. In addition, the UK and by 
extension NATO might be weakened if the referendum resulted in a reduction of military capabilities - including nuclear capabilities-and greater reluctance to deploy military forces abroad' (Walker 2014:747).

As the referendum vote drew near, the U.S. official position was indicated at the highest level, by the president. In June 2014, Obama stated that the U.S. preferred that the UK remained 'strong, robust, united, and effective', presumably at the urging of Prime Minister Cameron (quoted in Brooks and Carrell 2014; see also Walker 2014). Obama remarked that the UK appeared to have 'worked pretty well' (quoted in The Scotsman 2014), but acknowledged that the decision was 'up to the people of Scotland' (quoted in Brooks and Carrell 2014). The State Department reiterated the US preference against independence just days before the election (Sherwell, 2014). Finally, 'President Barack Obama made an 11th-hour appeal for Scots to vote no.....The unusual last-minute intervention by the President was a sign of concern in Washington that one of America's closest allies could be about to split in two. "The UK is an extraordinary partner for America and a force for good in an unstable world. I hope it remains strong, robust and united," Mr Obama said in a tweet' (Sanchez, 2014).

The implications for nuclear deterrence also worried the French government. According to Walker (2014: 747), France was less concerned about consequences for the EU: 'For France, the fate of the UK's Trident nuclear force was a singular worry.... [France] viewed the Scottish ambition to deprive the UK of its nuclear bases at Faslane and Coulport, and the absence of plausible alternatives in England and Wales, as seriously discomforting. There was no desire in Paris for France to become Europe's only nuclear-armed state.' Without the UK to play the role of a nuclear power, France's nuclear role would become more salient than the French public might be willing to accept. The French government also worried about the consequences for the UN Security Council. A diminished UK with a Security Council veto might strengthen arguments of other states seeking permanent seats (Walker 2014).

Other states also weighed in on the implications for the UK and for international relations. Chinese Premier Li Keqiang focused on the consequences for the UK: 'Speaking at a joint press conference with [UK Prime Minister] David 
Cameron, Li Keqiang said he wanted a 'strong, prosperous' Britain and a 'united United Kingdom' when asked about the referendum' (Riley-Smith, 2014). Australian Prime Minister Tony Abbott claimed that the world 'would not be helped' by Scottish independence (The Scotsman 2014), stating: 'I am a firm friend of the United Kingdom and I want it to remain the United Kingdom, not the disunited Kingdom. It is a matter for Scotland, obviously, but as a friend of the United Kingdom that is my view' (The Telegraph 2014).

Concern about threats to the European project of integration and a fragmentation of the international system were evident in others' reactions to the Scottish referendum. Spain's Foreign Minister García-Margallo warned that secession 'would end up in a Balkanisation process that nobody in Europe wants right now' (quoted in Roberts 2014) and Spanish Prime Minister Rajoy called the referendum 'a torpedo to the waterline of European integration', saying that 'Europe came together to join states together, not to break them apart.' Independence would be 'bad for the region, bad for the state and bad for the EU....there would be very little support for any such moves' (quoted in Johnson and Waterfield 2014). Former Swedish Prime Minister Bildt warned of a 'Balkanisation' of the British Isles (The Scotsman 2014). Former U.S. President Bill Clinton and former U.S. Secretary of State Madeleine Albright expressed concern over the dangers of European secessionist movements (Sanchez 2014). Pope Francis said that 'all division' worried him (Riley-Smith 2014).

The 'Yes' side's response to these warnings involved, in part, calling out hypocrisy. In reaction to Australian Prime Minister's anti-independence remarks, for example, First Minister Salmond described the comments as 'bewildering' (The Scotsman 2014) and replied that independence 'does not seem to have done Australia any harm' (Pearlman 2014). The SNP leader made similar comparisons to U.S. and Irish independence from Britain and invoked the international principle of self-determination (Salmond 2012). Such comments reflected again the value of a sovereign role itself.

The end game?: role rejection

The polls were close until the end. Surveys indicated a surge for the 'Yes' vote in August 2014, and some polls put 'Yes' in the lead for the first time since 
the Edinburgh Agreement was concluded. Ultimately, however the outcome of the bid for sovereignty was definitive and unsuccessful (What Scotland Thinks, 2014). On 18 September 2014, Scottish residents turned out to vote (an unusually high $84.6 \%$ ) on the question, 'Should Scotland be an independent country?' and a majority answered 'No', with 55.3\% voting against independence (BBC News 2014b). Scotland would not have a sovereign role in the world.

It is difficult to know if the international pre-socialisation efforts made any difference to voters' choices. Carrell (2014), for example, claims that the US position probably made no difference. Foreign and security policy were not major factors, according to public opinion surveys. Uncertainty, and particularly uncertainty over economic issues, were, however, extremely important and were connected to international socialisation efforts on, for example, EU membership (Bell, Delaney, and McGoldrick 2014). Abroad, the referendum was broadly met with a collective sigh of relief, and the reaction amongst concerned European actors was uniformly positive. José Manuel Barroso (President of the European Commission), Anders Fogh Rasmussen (Secretary General of NATO), and various other European leaders praised the referendum's outcome (Macdonald and Taylor 2014). German Chancellor Angela Merkel was comparatively circumspect: 'I will not comment on this but just smile' (Macdonald and Taylor 2014).

It is worth noting here that the independence debate could have looked dramatically different than it did, with perhaps a greater focus on identity distinctions, nationalism, and acrimonious recrimination about the past. While these aspects were present to some extent, a remarkable amount of effort was focused squarely on what roles Scotland and the rest of the UK could and could not play. This in turn framed debates about material conditions and capabilities, alliance potential, and economic uncertainties.

The question of independence, however, did not end with the 2014 referendum. A surge in SNP membership unexpectedly followed the vote, and in the May 2015 UK national elections, Scotland elected SNP candidates for 56 of its 59 national parliamentary seats. Moreover, in the immediate aftermath of the Brexit vote in June 2016, the Scottish First Minister Nicola Sturgeon stated that Brexit was a significant change in Scottish-UK circumstances and that a second independence referendum vote was therefore highly likely (BBC News 2016b). 
Whether another referendum would occur depends in part on internal Scottish and internal UK politics, but also on the nature of the UK exit negotiations with the EU and the position that key international actors take regarding Scotland's desire to remain within the EU. From a role theoretic perspective, the UK abandoned its EU role and thus calculations of the uncertainties associated with a sovereign Scottish role might change for many of those who argued against independence in 2014. Some of the pre-socialisation arguments regarding harm to European integration and unity may have much less punch given the UK's exit. In any event, any future bid for sovereignty by Scotland would undoubtedly trigger another round of pre-socialisation, but this would come in a new context in which the UK's role had dramatically changed.

\section{Conclusions}

Socialisation is an important concept in a wide range of international relations theories because it tells us something about the maintenance and order of the international society of sovereign states. Defining socialisation as an interactive process that is broader than norm internalization provides a way of examining what the current international system means to the agents themselves - what roles are possible, what roles are appropriate, and what roles are desired. Socialisation involves the mechanisms for maintaining the society's system of roles, and pre-socialisation extends this to the maintenance and definition of the sovereign system. Drawing on our investigation into international reactions to the Scottish independence referendum, we consider here the broader implications for role theory and state socialisation and the generalizability of insights from the Scottish case.

Similar to the socialisation processes of novice states noted by Thies (2013), international actors frequently sought to limit Scotland's ability to define its new role, and highlighted the small and uncertain nature an independent Scotland would have. Yet several aspects of pre-socialisation seen in the case differ from the socialisation of a novice state and have significant implications for our theoretical understanding of role socialisation. The pre-socialisation period places sovereignty more centrally in the process and reveals the nexus between sovereignty and roles. Whether an actor could become a sovereign 
state is intimately bound up with what role that state might take; these were virtually simultaneous within the Scottish case. The three aspects of the sovereignty-role nexus provide insights into state socialisation and how sovereignty relates to roles. We demonstrated that sovereignty itself is a role to be cast and that symbolic interactionism, contra a structural-functionalist view of sovereignty as a status, highlights the social construction of sovereignty. We also argued that how sovereignty is constructed helps shape the substantive roles available to states.

Pre-socialisation also exposes the meaning of sovereignty - how actors see its value, its content, its purpose. Philpott's (2001) arguments regarding the transformation of sovereignty by the EU can clearly be seen in the Scottish case, as can the more general debate over what independence means in an interdependent world, particularly for small states (Hassan and Mitchell 2013; Keating and Harvey 2014). Although the 'Yes' side was a nationalist independence movement and sovereignty was a value in and of itself, this independence movement hoped to retain pooled sovereignty within the EU. According to Bobor, visions of sovereignty in the 'Yes' campaign 'were never isolationist..., as the awareness of the necessity of international cooperation was often mentioned' (Bober 2014:31). This led some on the 'No' side to question the value of sovereignty, given the multi-level governance system of contemporary Europe. Somewhat ironically, Scotland sought autonomy but preferred to pool its sovereignty with the EU, while the UK opposed Scottish independence but preferred autonomy from the pooled EU sovereignty through its Brexit referendum.

Consistent with an English School perspective, the guardians of the international society, primarily the powerful states, acted to preserve the status quo. Contrary to other instances of guardians controlling the expansion of international society through a 'standard of civilization' and socialising revolutionary or 'rogue' states (e.g., Armstrong 1993; Bull and Watson 1984; Gong 1984), the response to Scotland in part rested on the notion that there would perhaps be too many sovereign states should Scotland achieve independence. This along with concerns about precedents for 'Balkanisation' reflects member-states' understanding of sovereignty: too much of a good thing 
may itself be a threat to the current society and international order. The international community seemed to be conveying the message, to paraphrase Lenin's views on liberty: 'sovereignty is precious, so precious that it must be rationed.'

Pre-socialisation also reveals the connected nature of roles and the implications of a new sovereign state for others' roles. Since Scotland was an aspirant state, its agency as a sovereign actor became entangled with the agency of the UK and its role in the international system. Much of the forecasting expressed by EU members, as well as NATO members, had less to do with how Scotland would enact its role post-independence and more to do with how the UK would be compromised in its ability to maintain its role in international politics. This duality of role pre-socialisation for Scotland and role anticipation for the rest of the UK reinforces the broader argument within role theory that roles are fundamentally interdependent, defined and redefined by the society of states within which they exist. This duality continued after the 2016 Brexit referendum as the question of a sovereign role for Scotland was once again on the table due to a dramatic shift in the UK's European role.

The Scottish independence case is clearly distinct from other independence movements in important ways. It came at a time of peace, prosperity, and stability, led by a left-of-centre party seeking interdependence rather than by a right-wing isolationist movement. Moreover Scotland already enjoyed significant autonomy through devolution, and the entire bid for sovereignty was itself sanctioned by the UK home state. The democratic nature of the referendum itself gave the process legitimacy in the eyes of most of the international community. This meant that when external actors did intervene, it was done primarily through the role contestation process (Cantir and Kaarbo 2016) within the referendum campaigns. The international community was not trying to persuade Scotland's government or political leaders, as is the case in most research on socialisation, but instead the target of socialisation was the Scottish voting public.

Although there are many cases of independence movements and even independence referenda (Coggins 2011; Mendez and Germann 2016), few share all of these characteristics. Within the European Union, Catalonia and Veneto are 
examples of other sub-state territories that have held independence referenda, but these have not been sanctioned by the home state (respectively Spain and Italy). Outside the EU, there have been recent independence referenda in Puerto Rico, Québec, East Timor, South Sudan, South Ossetia, and Montenegro, with only some of these with home state approval. Other secessionist movements, such as in Palestine, Chechnya, Aceh, and Tibet, have not had referenda but groups there still bid for a sovereign role. Each of these cases of attempted secession has unique characteristics and contexts that undoubtedly influence the international community's pre-socialisation efforts.

We expect, however, that the general arguments we have made here do apply to other cases. When other secessionist movements vie for independence (Eritrea, Kosovo, Somaliland, or South Sudan), they are seeking a sovereign role that must be negotiated and constituted by other actors. Others' reactions to secession will be influenced by the meaning of sovereignty at that time and in that context. ${ }^{13}$ Other cases of secession (e.g., Catalonia, Kurdistan, Montenegro, Québec, South Sudan) also involve forecasting substantive foreign policy roles, particularly given the consequences for the roles of the home state and the roles of others (Darmanovic 2003; McHugh 2015; Vela and Xifra 2015; Voller 2015, 2016). These cases, we argue, illustrate our broadest point that socialisation begins before statehood. Using role theory to understand pre-socialisation emphasises the common features that independence movements must navigate; they must strive for sovereignty as it is defined by existing actors, and the force of their argument for independence will be conditioned by available roles.

The Scottish case is valuable for understanding the sovereignty-role nexus precisely because it strips away many other complicating factors that are operative in other cases. There was no question of the possibility of violence with or without independence, an independent Scotland would not be antinormative, the right of self-determination and the legitimacy of the referendum were not in question. Still, the international community was largely opposed and actively 'intervened' to influence the referendum vote, socialising Scotland with regard to its forecasted sovereign and foreign policy roles. While other cases

13 On South Sudan, for example, see Christopher (2011); on small island independence movements, see Baldacchino and Hepburn (2012). 
introduce more complex layers of conflict, legitimacy, and norms, we would expect the sovereignty-role nexus to be a central feature. In other words, presocialisation of other actors seeking sovereignty would involve questions of what international roles they could play and the effects on the system of roles on the world stage.

Although we have made the case that pre-socialisation has distinct features that reveal the nexus between sovereignty and roles, we expect some of these to be present in other forms of state socialisation. Intriguingly, the UK's 2016 referendum to leave the EU created a somewhat parallel instance of socialisation. Even though the UK was already sovereign, the 'Leave' campaign arguments centred on a 'more' sovereign role, equating an EU role with the loss of sovereignty. Many arguments for and against Brexit echoed the themes of the Scottish independence debate on the value and meaning of sovereignty. In addition, there was a clear connection between a more independent role and the substantive foreign policy roles that the UK could play. Finally, the international community's reaction to Brexit and independence from the EU were similarly connected to the roles forecasted for other actors - could the EU continue to play its 'Global Power' role without the UK? Would the United States' role in the 'special relationship' between the United States and UK change after Brexit? The UK and Brexit is just one example of how the sovereignty-role nexus operates in other instances of socialisation. The Scottish case of pre-socialisation, distinct as it is, allowed us to focus on these theoretical aspects of socialisation that should be explored in future research.

The birth of a state has many midwives. A crowded international stage may perhaps have had room for one more actor, but such theatre is not improvisational. Instead, Scotland's bid for independence roused a host of concerned stakeholders who defended their interests and sought to influence the referendum outcome and effectively position themselves, and Scotland's role, in international society if independence was achieved. This was an interactive process, involving pro-independence Scottish actors and external actors forecasting potential roles for a new state. In the end, Scotland did not manage to be cast into a new sovereign role. To quote Lady Macbeth 'what's done is done', but the post-Brexit European theatre may have given this 'Scottish play' one 
more act, changing the cast of characters and opening the possibility of new dialogue to follow.

\section{Acknowledgements}

We are grateful for comments on earlier manuscript drafts from Cristian Cantir, Alexandra Remond, Yaniv Voller, the IR Research Group at the University of Edinburgh, participants at the Independence in an Interdependent and Multicultural World workshop at St Andrews, and anonymous reviewers. We owe special thanks to Hannah Solomon-Strauss for her research assistance.

\section{References}

Adamson, K. and P. Lynch (eds) (2014) Scottish Political Parties and the 2014 Independence Referendum. Cardiff: Welsh Academic Press.

Aggestam, L. (2006) Role Theory and European Foreign Policy: A Framework for Analysis. In O. Elgstrom and M. Smith (eds) The European Union's Roles in International Politics: Concepts and Analysis. London: Routledge, 11-29.

Alderson, K. (2001) Making Sense of State Socialization. Review of International Studies 27(3) 415-33.

Armstrong, D. (1993) Revolution and World Order: The Revolutionary State in International Society (Oxford: Clarendon Press).

BBC News, (2012a) SNP members voteto ditch the party's anti-Nato policy. 190ctober.

BBC News (2012b) Scottish independence: EC's Barroso says new states need 'apply to joinEU'. 10December.

BBC News (2014a). Scottish independence: Scotland could join EU in 18 months, says expert. 30 January.

BBC News. (2014b) How Scotland's 'No' vote resonates around the world. 19 September.

BBC News (2016a) EU Referendum: The results in maps and charts. 24 June. Available at: http://www.bbc.co.uk/news/uk-politics-36616028 (accessed 18 July 2016).

BBC News (2016b) Brexit: Nicola Sturgeon says second Scottish independence vote 'highly likely.' 24 June.

Barnett, M. (1993) Institutions, Roles, and Disorder: The Case of the Arab States System. International Studies Quarterly 37(3): 271-296.

Baxter, S. (n.d.) A Fair And Caring Scotland For All. Yes Scotland. Web. Accessed 1 Nov 2014. <http://www.yesscotland.net/reasons/fair-and-caringscotland-all>

Beasley, R., J. Kaarbo, \& H. Solomon-Strauss. (2016). To Be or Not To Be a State: Role Contestation in the Debate over Scottish Independence. In: Cantir C. and Kaarbo, J. (eds) Domestic Role Contestation, Foreign Policy, and International Relations. Routledge Publishers. 
Bell, D.N.F., L. Delaney, and M. McGoldrick (2014) Citizen Preferences for Constitutional Change in Scotland, University of Stirling and the Future of the UK and Scotland Report, May.

Beneš, V. and S. Harnisch (2015) Role theory in Symbolic Interactionism: Czech Republic, Germany, and the EU. Cooperation and Conflict 50(1): 146-165.

Bennett, A. (2014) Ryanair's Michael O'Leary Backs Scottish Independence Due To Air Passenger Duty Cut. The Huffington Post UK. 28 February.

Biersteker, T.J. and C. Weber (eds.) (1996) State Sovereignty as Social Construct. Cambridge: Cambridge University Press.

Bober, S. (2014) The Concept(s) of Sovereignty in the Scottish Independence Debate. Horizons of Politics 5(13): 11-39.

Breuning, M. (2011) Role Theory Research in International Relations: State of the Art and Blind Spots. In: Harnisch S, Frank C and Maull HW (eds) Role Theory in International Relations: Approaches and Analyses. New York: Routledge, 16-35.

Brittain, A. (2014) U.K. currency debate heats up. The Wall Street Journal, 16 March.

Brooks, L. and S. Carrell (2014) Obama's Scottish Independence Intervention Gets Cautious Reaction. The Guardian 7 June 2014.

Brown, Gordon (2014) My Scotland, Our Britain: A Future Worth Sharing. London: Simon \& Schuster.

Buck, T. and M. Dickie (2014) Spain Promises Non-Interference on Scotland. Financial Times, 2 February.

Bull, H. (1977) The Anarchical Society: A Study of Order in World Politics. New York: Columbia University Press.

C-SPAN (2014) Scottish Independence Debate. 25 August. Web. Accessed 7 July 2015. <http://www.c-span.org/video/?321045-1/scottish-independencedebate>

Cantir, C. (2011) The Allied Punishment and Attempted Socialisation of the Bolsheviks (1917-1924): An English School Approach. Review of International Studies 37(4):1967-1994.

Cantir C. and Kaarbo J. (eds) (2016) Domestic Role Contestation, Foreign Policy, and International Relations. London: Routledge.

Carrell, S. (2013) Nato Rejects Alex Salmond Claim Over Scottish Membership. The Guardian 10 April.

Carrell, S. (2014) Shell Boss Warns against Scottish Independence. The Guardian. 6 March.

Castle, S. and S. Reed (2014) Scottish Oil and Gas anIssue in Vote on Independence. The New York Times, 24 February.

Checkel, J.T. (2005) International Institutions and Socialization in Europe: Introduction and Framework. International Organization 59(4): 801-26.

Christopher, A.J. (2011) Secession and South Sudan: An African precedent for the future? South African Geographical Journal 93(2):125-132.

Coggins, B. (2011) Friends in High Places: International Politics and the Emergence of States from Secessionism. International Organization 65: 433-467.

Darmanovic, S. (2003) Montenegro: The Dilemmas of a Small Republic. Journal of Democracy 14(1):145-153. 
Duchêne, F. (1972) 'Europe's role in world peace', in R. Mayne (ed.), Europe Tomorrow, London: Fontana, pp. 32-47.

Flockhart, T. (2004) 'Masters and Novices': Socialization and Social Learning in NATO-Parliamentary Assembly, International Relations 18(3): 361-80.

Ford, M. (2014) 'UK to Russia: Crimea Isn't Scotland,' The Atlantic, 17 March.

The Guardian, (2013) "David Cameron tries to put the brakes on Alex Salmond", 11 February.

Hardman, I. (2014) Salmond attacks credibility of 'No' campaign threats. In: Coffee House blog, The Spectator 24 February.

Harnisch, S. (2011) Role Theory: Operationalization of Key Concepts. In: Harnisch, S., C. Frank, and H.W. Maull (eds) Role Theory in International Relations: Approaches and Analyses, London: Routledge.

Harnisch , S. (2016) Role Theory and the Study of Chinese Foreign Policy. In: Harnisch, S., S, Bersick, and J-C. Gottwald (eds) China's International Roles. London: Routledge.

Harnisch, S., S. Bersick, and J-C. Gottwald (eds) (2016) China's International Roles. London: Routledge

Harnisch, S., C Frank and H.W. Maull (eds) (2011) Role Theory in International Relations. London: Routledge.

Hassan, G. and J. Mitchell (eds.) After Independence Edinburgh: Luath Press Limited.

Herald Scotland (2014) "Independence Would Not Bar Scotland From EU Membership." 1 March.

Holsti, K.J. (1970) National Role Conceptions in the Study of Foreign Policy, International Studies Quarterly 14: 233-309.

Jackson, B. (2014) The Political Thought of Scottish Nationalism, Political Studies $47(3): 50-56$.

Jackson, R. (2000) The Global Covenant: Human Conduct in the World of States. Oxford: Oxford University Press.

Johnson, S. (2014) Spanish warn independent Scotland would get euro not pound, The Telegraph 16 September 2014.

Johnson, S. and B. Waterfield (2014) Spanish Prime Minister gives EU warning to Scots. The Telegraph 17 September.

Johnston, A.I. (2005) Conclusions and Extensions: Toward Mid-Range Theorizing and Beyond Europe, International Organization 59:1013-1044.

Keating, M. and M. Harvey (2014) Small Nations in a Big World: What Scotland Can Learn? Edinburgh: Luath Press Limited.

King, C. (2012) The Scottish Play: Edinburgh's Quest for Independence and the Future of Separatism, Foreign Affairs, September/October.

Liddington, D. (2014) Press release: Prospects of EU membership for a newly independent Scotland. Foreign and Commonwealth Office, UK Government, 16 January.

MacAskill, E., J. Kaiman, and J. Burke (2013) Obama Administration Reiterates Belief UK Is Stronger Within EU, The Guardian 23 January.

MacDonald, Alastair and Paul Taylor (2014) EU Relief of Scotland's 'No' vote Tinged with Fear of Nationalism, Reuters New Agency.

Manners, I. (2002) 'Normative Power Europe: A Contradiction in Terms?', Journal of Common Market Studies 40(2): 235-258. 
Maull, H.W. (1990) Germany and Japan: The New Civilian Powers. Foreign Affairs 69(5): 91-106.

McCarthy, M. (2014) If Scotland Votes Yes, What Could It Mean For Fishing, Farming And Wildlife? The Independent. 8 September.

McCourt, D.M. (2012) The Roles States Play: A Meadian Interactionist Approach, Journal of International Relations and Development 13(3): 370-392.

McHugh, J.T. (2015) Paradiplomacy, Protodiplomacy and the Foreign Policy Aspirations of Quebec and Other Canadian Provinces. Canadian Foreign Policy Journal 21(3): 238-256.

Nelson, D. (2014) Indians fear Scottish independence could raise Scotch price. The Telegraph 17 September.

The New York Times, (2013) A Vote on Scottish Independence, (Editorial), 27 March.

Pearlman, J. (2014) Australians divided over Scottish referendum The Telegraph 16 September.

Riley-Smith, B. (2014) Scottish independence: China's premier says he wants a 'united United Kingdom'. The Telegraph 18 June.

Roberts, M. (2014) Spain says Scottish independence would be a 'catastrophe'. The Telegraph, 17 September.

Saideman, S.M. (1997) Explaining the International Relations of Secessionist Conflict: Vulnerability vs. Ethinic Ties, International Organization 51:721753

Salmond, A. (2012) Scotland Should be Independent, The Washington Post, 7 December.

Sanchez, R. (2014) Barack Obama tells Scotland: stay united The Telegraph, 17 September.

Schimmelfennig, F. (2000) International Socialization in the New Europe: Rational Action in an Institutional Environment. European Journal of International Relations 6: 109-139.

The Scotsman, Scottish Independence: Global Reaction, 16 September 2014.

Scottish Government (2013) Scotland's Future: Your Guide to an Independent Scotland. Edinburgh.

Sherwell, P. (2014) White House calls for Britain to remain a 'united' partner. The Telegraph 15 September.

Sparrow, A. (2014) George Osborne's speech on Scottish Indpendence. In: Politics live blog. The Guardian 13 February.

Stryker and Stratham (1985) Symbolic Interactionism and Role Theory. In: G. Lindsey and E. Aronson (eds) Handbook of Social Psychology, Vol.1 (New York: Random House).

Sturgeon, N. (2013) Evidence to UK House of Commons Foreign Affairs Committee, 28 January; http://www.publications.parliament.uk/pa/cm201213/cmselect/cmfaff/6 43/130128.htm, accessed 17 May 2015.

The Telegraph, (2014) Scottish independence: How the world has reacted 18 September.

Thies, C.G. 2003. Sense and Sensibility in the Study of State Socialization: A Reply to Kai Alderson. Review of International Studies 29(4): 543-550. 
Thies, C.G. (2010a) Role Theory and Foreign Policy,. In: R.A. Denemark (Ed.) The International Studies Encyclopedia, (Oxford: Blackwell); Blackwell Reference Online.

Thies, C.G. (2010b) State Socialization and Structural Realism, Security Studies 19(4): 689-717.

Thies, C.G. (2012) International Socialization Processes vs. Israeli National Role Conceptions: Can Role Theory Integrate IR Theory and Foreign Policy Analysis? Foreign Policy Analysis 8:25-46.

Thies, C.G. (2013) The United States, Israel, and the Search for International Order: Socializing States. London: Routledge.

Thies, C.G. (2016) The US and China: Altercast Roles and Changing Power in the $20^{\text {th }}$ Century. In: Harnisch, S., S, Bersick, and J-C. Gottwald (eds) China's International Roles. London: Routledge.

Vela, J.D.S.E, and J. Xifra (2015) International Representation Strategies for Stateless Nations: The Case of Catalonia's Cultural Diplomacy. Place Branding and Public Diplomacy 11(1):83-96.

Voller, Y. (2015) Contested Sovereignty as an Opportunity: Understanding Democratic Transitions in Unrecognized States. Democratization 22(4):610-630.

Voller, Y. (2015) The Egyptian Muslim Brotherhood and the South Sudan Question: Reconsidering Moderation. International Affairs 92(3):665-682.

What Scotland Thinks (2014) Should Scotland be an independent country?. Available at: http://whatscotlandthinks.org/questions/should-scotlandbe-an-independent-country\#line

Walker, S.G. (1987). Role Theory and Foreign Policy Analysis. Durham, N.C.: Duke University Press.

Walker, S.G. (1992) Symbolic Interactionism and International Politics: Role Theory's Contribution to International Organization. In: Contending Dramas: a Cognitive Approach to International Organizations, edited by Martha Cottam and Chih-yu Shih, 19-38. New York: Praeger.

Walker, W. (2014) International Reactions to the Scottish Referendum, International Affairs 90(4):743-759.

Waltz, K.N. (1979) Theory of International Politics. New York: McGraw-Hill.

The Washington Post (2012) Scottish Independence Vote is Part of Worrying Trend, (Editorial) 31 October.

Wehner, L.E. (2014) Role Expectations As Foreign Policy: South American Secondary Powers' Expectations of Brazil As A Regional Power. Foreign Policy Analysis, doi: 10.1111/fpa.12048

Wehner, L.E. and C.G. Thies (2014) Role Theory, Narratives, and Interpretation: The Domestic Contestation of Roles, International Studies Review 16(3):411-436.

Wendt, A. (1992) Anarchy is What States Make of It: The Social Construction of Power Politics, International Organization 46:391-425.

Wentworth, W.M. (1980) Context and Understanding: An Inquiry Into Socialization Theory (NY: Elsevier).

Wight, M. (1977) International Legitimacy. In H. Bull (ed.) Systems of States. Leicester: Leicester University Press.

Wish, N.B. (1980) Foreign Policy Makers and National Role Conceptions, International Studies Quarterly 24(4):532-54. 
